\title{
Analisi Pembangkit Listrik Tenaga Mikrohidro Menggunakan Sistem Distribusi Air di P.T. Astra Honda Motor Plant 5 Karawang
}

\author{
Deni Almanda ${ }^{1}$, Rahmat Kartono ${ }^{2}$ \\ 1) 2) Teknik Elektro Universitas Muhammadiyah Jakarta \\ Jl. Cempaka Putih Tengah 27 No 47 \\ Email: ${ }^{1)}$ deni.almanda@ftumj.ac.id, ${ }^{2}$ 2012420101@ftumj.ac.id
}

\begin{abstract}
ABSTRAK
Energi listrik merupakan salah satu kebutuhan vital yang tidak bisa dipisahkan bagi masyarakat pada umumnya maupun perusahaan industri khususnya. Maka dari itu mendorong pelaku usaha untuk melakukan suatu pengolahan energi yang beretujuan meningkatkan efisiensi energi dan juga mencari sumber energi yang terbarukan seperti air, angin, surya dan lain-lain.Pembangkit Listrik Tenaga Mikrohidro (PLTMH) merupakan salah satu energi listrik alternatif yang mempunyai beberapa kelebihan diantaranya tidak memakai bahan bakar dan sumber energi didapat dengan gratis. Menurut Larasakti (2012:245) jadi pada prinsipnya dimana ada air mengalir dengan ketinggian minimal 2,5 meter dengan debit 250 liter/detik, maka disitu ada energi listrik.Pada Pembangkit Listrik Tenaga Mikrohidro (PLTMH) PT Astra Honda Motor menggunakan generator dengan output 1100 watt serta sumber energi memanfaatkan aliran sirkulas air cooling tower dengan debit 2000 lpm serta head total 7 meter. Berdasarkan data tersebut didapatkan potensi energi sebesar 1152,82 watt. Pada aktualnya PLTMH menghasilkan energi sebesar 950,4 watt. Berdasarkan data tersebut dapat kita simpulkan bahwa PLTMH tersebut hanya menghasilkan 83,16\% dari kapasitasnya.
\end{abstract}

\section{Kata Kunci : PLTMH, Generator Innduksi, Turbin Air}

\begin{abstract}
Electrical energy is one of the vital needs that can not be separated for the community in general and industrial companies in particular. Therefore encourage businesses to carry out an energy treatment that is agreed to improve energy efficiency and also look for renewable energy sources such as water, wind, solar and others. the advantages include not using fuel and energy sources obtained for free. According to Larasakti (2012: 245) so in principle where there is running water with a minimum height of 2.5 meters with a discharge of 250 liters / second, there is electrical energy. In the Micro Hydro Power Plant (PLTMH) PT Astra Honda Motor uses a generator with an output 1100 watts as well as an energy source utilizing the cooling tower water circulation flow with a discharge of $2000 \mathrm{lpm}$ and a total head of 7 meters. Based on these data an energy potential of 1152.82 watts was obtained. Actually the PLTMH produces 950.4 watts of energy. Based on these data, we can conclude that the PLTMH only produces $83.16 \%$ of its capacity.
\end{abstract}

Keywords: MHP, Innduction Generator, Water Turbine

\section{PENDAHULUAN}

Energi listrik dan merupakan salah satu kebutuhan vital yang tidak bisa dipisahkan bagi masyarakat pada umumnya maupun perusahaan industri khususnya. Di dalam perkembangannya di bidang industri, listrik sudah menjadi tulang punggung pada semua aktifitas yang ada di sebuah perusahaan. Maka dari itu mendorong pelaku usaha untuk melakukan suatu pengolahan energi yang beretujuan meningkatkan efisiensi energi dan juga mencari sumber energi yang terbarukan seperti air, angin, surya dan lain-lain. Salah satu sumber energi terbarukan yang sudah dikembangkan menjadi energi listrik adalah energi air [1]. Baru-baru ini, banyak pembangkit listrik mikrohidro yang terhubung ke jaringan distribusi melalui elektronika daya [2].

Mikrohidro merupakan salah satu sumber energi terbarukan. Mikrohidro adalah istilah untuk instalasi pembangkit listrik yang menggunakan energi air [3]. Pembangkit Listrik Tenaga Mikrohidro (PLTMH) dapat dimanfaatkan sebagai salah satu kebutuhan untuk ketahanan nasional di bidang energi [4]. Masih banyak daerah terpencil yang belum tersentuh elektrifikasi karena tidak dapat diaksesnya daerahdaerah tersebut oleh infrastruktur listrik yang ada. Daerah-daerah terpencil ini sebenarnya menyimpan potensi tenaga air yang dapat digunakan untuk menghasilkan listrik [5]. Mikrohidro atau yang dimaksud dengan Pembangit Listrik Tenaga 
Mikrohidro yaitu pembangkit listrik skala kecil dengan air sebagai tenaga penggeraknya, pada umumnya penempatan mikro hidro dekat aliran sungai, aliran irigasi ataupun air terjun dengan memanfaatkan debit air dan beda ketinggian (head) untuk menggerakkan turbin. Mikro hidro merupakan salah satu energi listrik alternatif yang mempunyai beberapa kelebihan diantaranya murah biaya produksinya, sumber tenaga diperoleh dengan gratis dan tidak terpengaruh kenaikan harga bahan bakar.

Menurut [6] jadi pada prinsipnya dimana ada air mengalir dengan ketinggian minimal 2,5 meter dengan debit 250 liter/detik, maka disitu ada energi listrik. Selain daripada itu mikro hidro tidak perlu membuat waduk yang besar seperti PLTA, sayangnya sampai sekarang ini teknologi PLTMH di masyarakat masih kurang familier sehingga pertumbuhannya juga lambat.

Saat ini, perkembangan dunia teknologi yang demikian mengagumkan itu telah membawa manfaat yang luar biasa bagi kemajuan peradaban umat manusia [7]. Energi sangat penting untuk manusia untuk bisa bertahan hidup [8]. Dalam perkembangan teknologi saat ini, listrik menjadi salah satu kebutuhan yang sangat penting bagi kehidupan masyarakat, baik dalam rumah tangga maupun dalam bidang industri [9]. Sumber energi fosil seperti minyak bumi, gas alam dan batubara akan bisa bertahan jika sumber energi terbarukan digunakan [10]. Salah satu bahan semikonduktor organik yang sering digunakan adalah pentacene karena ketersediaannya dan kinerja divaisnya [11]. Pada saat ini berkembang pesat pembangunan gedung gedung pencakar langit di berbagai belahan dunia dan gedung tersebut pasti membutuhkan transportasi vertical [12]. Material organik telah menjadi perhatian para peneliti meskipun karakternya kurang dari silikon [13]. Dengan adanya Internet of Things dapat memudahkan pengguna saat mengakses atau menggunakan piranti yang berada pada jarak jauh [14]. Pada perkembangan teknologi saat ini perusahaan - perusahaan semakin gencar untuk mendatangkan mesin - mesin dengan teknologi - teknologi cangih dan modern, sehingga perusahaan pun semakin ketat untuk dapat menghasilkan produk - produk dengan kualitas dan mutu yang baik dan tepat sasaran serta efektif dan efesien [15]. Semakin pesatnya perkembangan dunia otomotive khususnya kendaraan roda 4 atau yang sering kita sebut mobil, mendorong para produsen kendaraan mobil ini untuk berinovasi mengembangkan teknologi pada kendaraan yang di produksi [16]. Dalam penelitian ini penulis mencoba menganalisis kelayakan teknis dan juga daya yang dihasilkan mikrohidro pada PT Astra Honda Motor
Karawang. PT Astra Honda Motor Karawang merupakan plant terbesar di indonesia yang membutuhkan pasokan energi listrik sebesar $2 \mathrm{MW}$, maka dari itu perlu inovasi-inovasi untuk mengurangi beban energi listrik dari PLN.

\section{METODOLOGI}

Dalam penelitian ini penulis mendapatkan data dengan berbagai cara sebagai berikut :

- Studi literatur, untuk memperoleh bahan acuan sebagai dasar terori dan metode perhitungan yang digunakan sesuai dengan materi bahasan.

- Pengujian terhadap PLTMH untuk mendapatkan data-data aktual yang nantinya sebagai pembanding data yang didapat dengan metode teoritis.

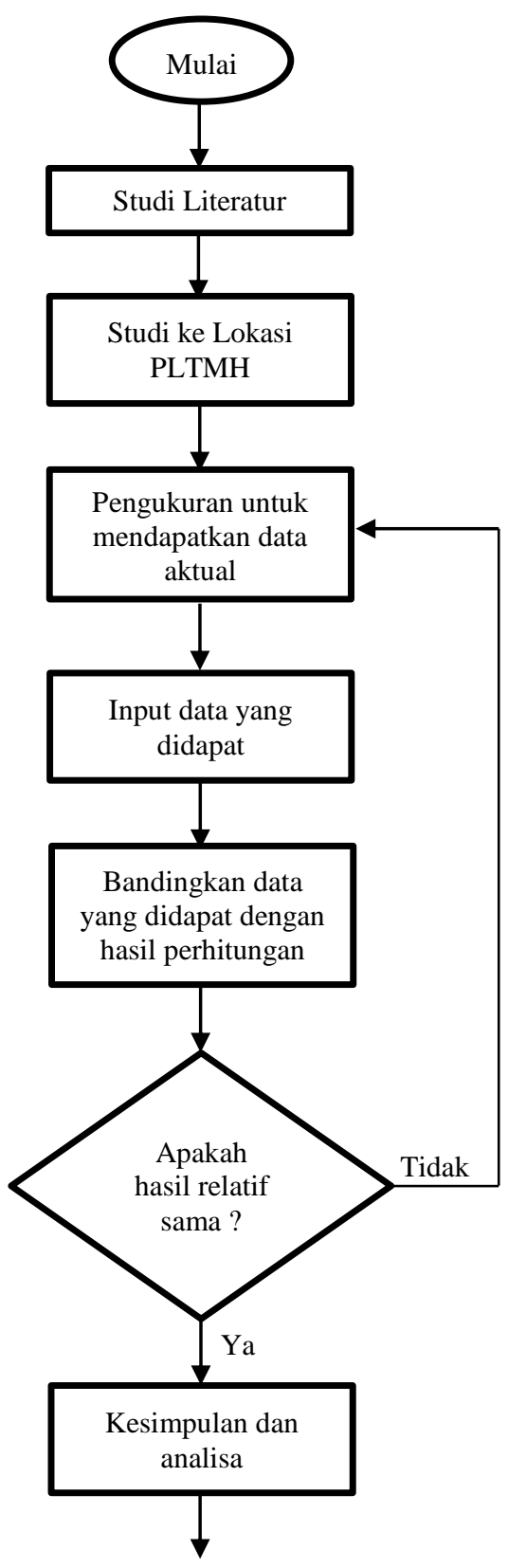




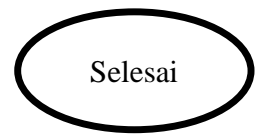

Gambar 1 Diagarm alur penelitian.

\section{HASIL DAN PEMBAHASAN}

Besarnya kapasitas suatu pembangkit PLTMH ditentukan oleh besarnya debit dan tingginya head. Semakin besar debit, semakin besar kapasitas terpasang begitu juga head - semakin tinggi head maka semakin tinggi pula kapasitas terpasang. Akan tetapi karena adanya gravitasi bumi, dan effciency Turbines serta eficiency Generators, maka koreksi terhadap kapasitas terpasang harus di pertimbangkan dalam perhitungan.

PLTMH selalu menggunakan Rumus berikut untuk menentukan kapasitas terpasang, yaitu :

$\mathrm{E}=\mathrm{Q} \times \mathrm{h} \times \mathrm{g} \times \mathrm{e} \mathrm{T} \times \mathrm{e} \mathrm{G} \times \mathrm{eTr}$

Dimana :

$\mathrm{E}=$ Potensi Energi

$\mathrm{Q}=$ Debit Air

$\mathrm{h}=$ Head

$\mathrm{g}=$ Gravitasi bumi $(9,81)$

$\mathrm{eT}=$ Efisiensi turbin

$\mathrm{eG}=$ Efisiensi generator

$\mathrm{eTr}=$ Efisiensi transmisi

Bagian-bagian Pembangkit listrik tenaga mikrohidro:

- Bak penampung, bak penampung pada PLTMH PT Astra Honda Motor awalnya hanya untuk membackup sistem existing saja, dengan adanya PLTMH maka sekarang menjadi dwi fungsi.

Bak tersebut terbuat dari beton bertulang, terdiri dari bak penampung dingin dan bak penampung panas. Bak penampung dingin mendapat distribusi dari return cooling tower dan bak penampung panas mendapat distribusi dari return mesin-mesin kompressor, masing-masing bak berkapasitas $71 \mathrm{~m}^{3}$.

- Saluran Pembawa (headrace), Pada umumnya saluran pembawa PLTMH bertipe Saluran terbuka, dimana memiliki kelemahan pasir, ranting, dedaunan, sampah plastik dan sejenisnya akan bebas masuk kedalam saluran. Tetapi untuk PLTMH ini saluran pembawa menggunakan pipeline existing atau saluran tertutup.

- Bak Penenang (Forebay), Bak penenang pada PLTMH ini menggunakan unit cooling tower existing yang berkapasitas $2000 \quad 1 / m$. Kekurangan dari cooling tower yakni tidak adanya bak pengendap yang berfungsi untuk mecegah terjadinya Vortexes (pusaran air) sebelum masuk melalui pipa pesat menuju turbin. Pada umumnya bak pengendap dan bak penenang dibatasi dengan saringan agar kotorankotoran tidak terbawa masuk. Sedangkan pada cooling tower tidak membutuhkan saringan lagi dikarenakan pada saluran pembawa sudah dilengkapi dengan saringan, jadi air yang masuk ke dalam cooling tower sudah bebas dari kotoran.

- Pipa Pesat (Penstock), Pipa pesat yang digunakan berjumlah dua buah disusun berbaris yang berfungsi menerjunkan air menuju turbin. Pipa pesat mempunyai posisi kemiringan yang tajam dengan maksud agar diperoleh kecepatan dan tekanan air yang tinggi untuk memutar turbin. Konstruksinya harus diperhitungkan agar dapat menerima tekanan besar yang timbul termasuk tekanan dari pukulan air. Adapun ukuran existing pipa pesat ini yaitu 8 inc. Besarnya pipa dapat kita hitung dengan persamaan :

Dimana :

$$
\mathrm{D}=\sqrt{ } \frac{4 \cdot \mathrm{Q}}{\pi \cdot \mathrm{V}}
$$

$\mathrm{Q}=$ debit air $(\mathrm{l} / \mathrm{s})$

$\mathrm{V}=$ kecepatan aliran air $(\mathrm{m} / \mathrm{s})$

$\mathrm{D}=$ diameter pipa (inc)

Dengan menggunakan rumusan di atas dan memasukkan data yang didapat maka diperoleh hasil

$$
\begin{gathered}
\mathrm{D}=\sqrt{ } \frac{4 \times 33,33}{\pi \times 2} \\
\mathrm{D}=4,607=5 \text { inc }
\end{gathered}
$$

Melihat hasil perhitungan diatas diameter pipa yang digunakan cukup dengan 5 inc saja, sedangkan pipa existing berukuran 8 inc berarti 1,5 kali lebih besar dari perhitungan.

- Rumah Pembangkit (Power House), pada umumnya diklassifikasi menjadi tiga (3) tipe, yaitu tipe diatas tanah, tipe semi diatas tanah dan tipe dibawah tanah. Power house pada PLTMH ini merupakan satu kesatuan dengan sistem PLTMH itu sendiri dengan kata lain dalam satu gedung sudah mencakup semua sistem yang ada. Bangunan terdiri dari 2 lantai dan 1 basement dengan luas tiap lantai $324 \mathrm{~m}^{2}$ Di basement terdapat bak penampung, pompa air, turbin beserta generator. Lantai 1 terdapat panel kontrol dan lantai 2 terdapat bak penenang. 
RESISTOR (Elektronika Kendali Telekomunikasi Tenaga Listrik Komputer) Vol. 3 No. 1 e-ISSN : 2621-9700, p-ISSN : 2654-2684

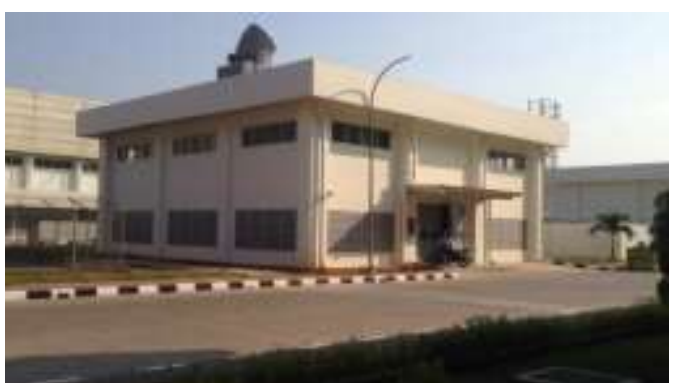

Gambar 2 Gedung utility / rumah pembangkit.

- Turbin, PLTMH di PT Astra Honda Motor, menggunakan turbin propeller dengan mempertimbangkan beberapa kriteria yaitu turbin sangat efektif pada head yang rendah. Besar daya yang dihasilkan dapat kita hitung dengan persamaan :

$$
\begin{gathered}
\mathrm{P} \text { in turbin }=\mathrm{Q} \times \mathrm{g} \times \mathrm{H} \\
\mathrm{P} \text { out turbin }=\mathrm{Q} \times \mathrm{g} \times \mathrm{H} \times \mathrm{eT}
\end{gathered}
$$

P out gen $=\mathrm{Q} \times \mathrm{g} \times \mathrm{H} \times \mathrm{eT} \times \mathrm{eG} \times \mathrm{eTr}$

Dimana :

$\mathrm{P}=$ daya yang dihasilkan (watt)

$\mathrm{Q}=$ debit air $(\mathrm{l} / \mathrm{s})$

$\mathrm{g}=$ gravitasi. $(9,81 \mathrm{~m} / \mathrm{s})$

$\mathrm{H}=$ tinggi jatuh air $(\mathrm{m})$

$\mathrm{eT}=$ efisiensi Turbin $(75 \%)$

$\mathrm{eG}=$ efisiensi Generator $(73 \%)$

eTr = efisiensi transmisi (95\%)

Dengan menggunakan rumusan di atas dan memasukkan data yang didapat maka diperoleh hasil $\mathrm{P}$ in turbin $=33,33 \times 9,81 \times 6,5=2125,28$ watt

$\mathrm{P}$ out turbin $=33,33 \times 9,81 \times 6,5 \times 0,75$

$$
=1593,96 \text { watt }
$$

$\mathrm{P}$ out gen

$=33,33 \times 9,81 \times 6,72 \times 0,75 \times 0,73 \times 0,95$

$=1142,82$ watt

- Generator, Generator yang digunakan pada pembangkit ini merupakan generator asinkron/induksi 3 phasa $220 / 380 \mathrm{~V}, 50 \mathrm{~Hz}$. Kapasitas dari generator ini $1,1 \mathrm{~kW}$ dan untuk frekuensi generator dipengaruhi oleh jumlah putaran stator dari generator.

Tabel 1 Spesifikasi generator asinkron / induksi.

\begin{tabular}{|l|l|}
\hline Brand & TECO Motor \\
\hline Output & $1,5 \mathrm{HP} / 1,1 \mathrm{~kW}$ \\
\hline Pole & 4 \\
\hline Frekuensi & $50 \mathrm{~Hz}$ \\
\hline Voltase & $220 / 380 \mathrm{~V}$ \\
\hline
\end{tabular}

\begin{tabular}{|l|l|} 
Rotary & 1425 \\
\hline Ampere & $4,77(\Delta), 2,76(\mathrm{Y})$ \\
\hline Cos Phi & 0,84 \\
\hline
\end{tabular}

Dari data di atas dapat kita ketahui nilai efisiensi sebuah generator dengan perhitungan sebagai berikut .

$$
\mathrm{eG}=\frac{\mathrm{P} \text { out }}{\mathrm{P} \text { in }} \times 100 \%
$$

untuk dapat mencari nilai efisiensi, perlu dicari terlebih dahulu $\mathrm{P}$ in. Yaitu dengan perhitungan sebagai berikut.

$$
\mathrm{P} \text { in }=\mathrm{V} \mathrm{x} \mathrm{I} \times \cos \varnothing \mathrm{x} \sqrt{3}
$$

Dimana :

$\mathrm{P}=$ daya input (watt)

$\mathrm{V}=$ tegangan (volt)

$\mathrm{I}=\operatorname{arus}(\mathrm{amp})$

$\cos \varnothing=0,84$

$\mathrm{P}$ in $=380 \times 2,76 \times 0,84 \times \sqrt{3}=1524,11$ watt

Maka nilai efisiensi generator dapat kita hitung:

$\mathrm{eG}=\frac{\mathrm{P} \text { out }}{\mathrm{P} \text { in }} \times 100 \%$

$\mathrm{eG}=\frac{1,1 \mathrm{kw}}{1,52 \mathrm{kw}} \times 100 \%$

$\mathrm{eG}=73 \%$

\begin{tabular}{|c|c|c|c|}
\hline $\begin{array}{l}\text { Beban } \\
\text { (watt) }\end{array}$ & $\begin{array}{l}\text { Tegangan } \\
\text { (V) }\end{array}$ & $\begin{array}{l}\text { Frekuensi } \\
\text { (f) }\end{array}$ & $\begin{array}{l}\text { Putaran } \\
\text { generator } \\
\text { (rpm) }\end{array}$ \\
\hline 0 & 220 & 55,3 & \multirow{6}{*}{1625} \\
\hline 200 & 220 & 54,9 & \\
\hline 400 & 218,5 & 54,4 & \\
\hline 600 & 217 & 53,5 & \\
\hline 800 & 215,5 & 52,8 & \\
\hline 1000 & 214 & 51,5 & \\
\hline
\end{tabular}

Pada percobaan 1 penulis mencoba mengamati perubahan yang terjadi pada PLTMH dengan beban, 10 lampu pijar (100 watt/lampu).

Tabel 2 Pengujian dengan beban lampu pijar. 
RESISTOR (Elektronika Kendali Telekomunikasi Tenaga Listrik Komputer) Vol. 3 No. 1 e-ISSN : 2621-9700, p-ISSN : 2654-2684

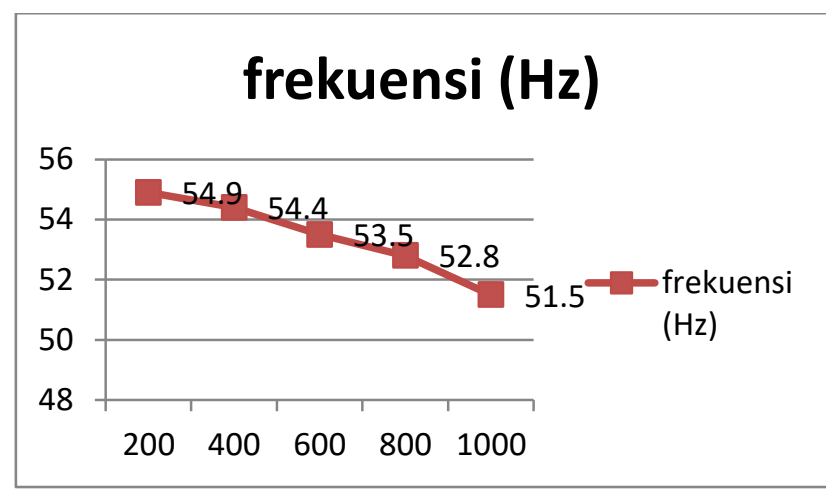

Gambar 3 Hubungan frekuensi terhadap perubahan beban.

Pada tabel 1 menunjukkan bahwa pembebanan dengan menggunakan lampu pijar berpengaruh terhadap frekuensi yang dihasilkan oleh generator walaupun tidak signifikan, tabel di atas menunjukkan semakin besar beban pada PLTMH maka frekuensi akan semakin turun. Demikian pula dengan tegangan semakin besar pembebanan maka tegangan akan semakin turun. Semakin tinggi daya beban yang dipikul generator maka tegangan dan frekuensinya akan menurun (Supardi et al., 2014) Percobaan 2

Pada percobaan 2 penulis mencoba mengamati perubahan yang terjadi pada PLTMH dengan mengatur posisi katup (membuka/menutup).

Tabel 3 Pengujian dengan mengatur katup valve.

\begin{tabular}{|l|l|l|l|l|l|}
\hline $\begin{array}{l}\text { Posis } \\
\text { i katup }\end{array}$ & $\begin{array}{l}\text { Tegan } \\
\text { gan } \\
(\mathrm{V})\end{array}$ & $\begin{array}{l}\text { Frekue } \\
\text { nsi (f) }\end{array}$ & $\begin{array}{l}\text { Hea } \\
\text { (m) }\end{array}$ & $\begin{array}{l}\text { Aru } \\
\text { s } \\
(\mathrm{A})\end{array}$ & $\begin{array}{l}\text { Putara } \\
\mathrm{n}\end{array}$ \\
$\begin{array}{l}\text { Genera } \\
\text { tor } \\
\text { (rpm) }\end{array}$ \\
\hline $\begin{array}{l}100 \\
\%\end{array}$ & 220 & 55,3 & 6,5 & 4,8 & 1625 \\
\hline $75 \%$ & 220 & 53,5 & 7 & 4,4 & 1570 \\
\hline $50 \%$ & 196 & 49,5 & 8 & 4 & 1491 \\
\hline $25 \%$ & 178 & 46,6 & 8 & 3,5 & 1390 \\
\hline
\end{tabular}

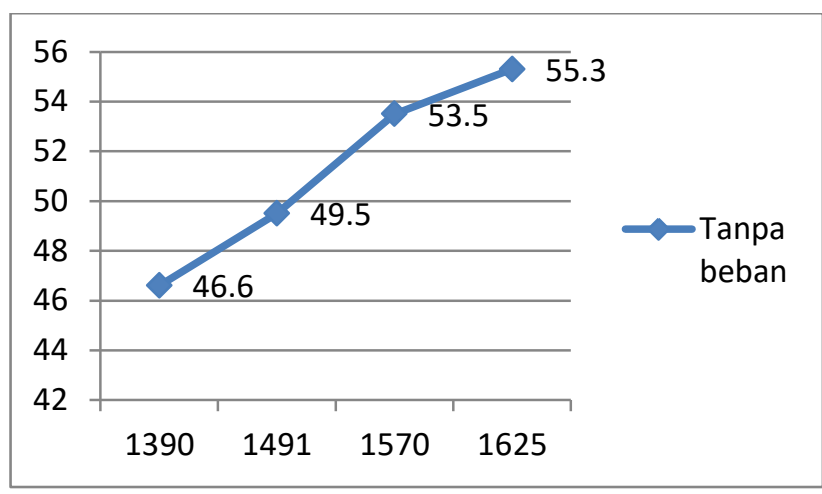

Gambar 4 Hubungan kecepatan putar terhadap frekuensi tanpa beban.

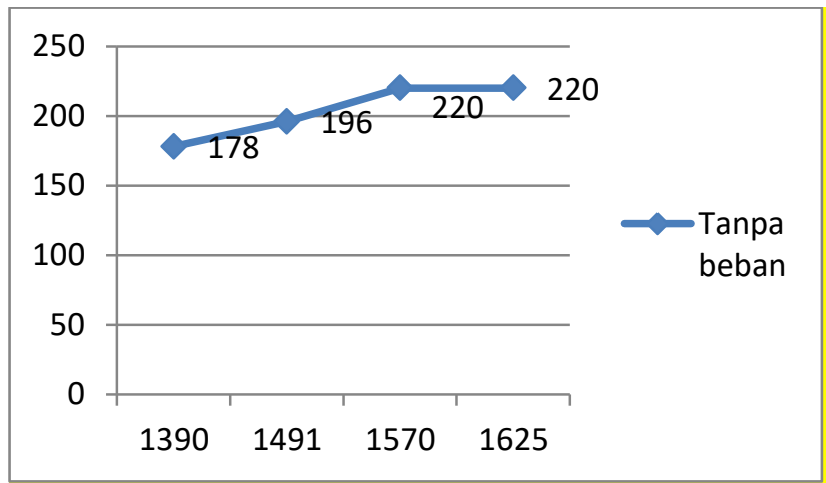

Gambar 5 Hubungan kecepatan putar terhadap tegangan.

Pada tabel 2 data diambil sebanyak 4 kali pengujian, pada mulanya generator PLTMH mempunyai kecepatan $1625 \mathrm{rpm}$, perlahan-lahan katup valve dibuka $75 \%$ sehingga mendapatkan kecepatan $1570 \mathrm{rpm}$ dengan frekuensi 55,3 Hz. Berdasarkan tabel 4.2 semakin tinggi kecepatan putar generator maka frekuensi juga semakin bertambah.

Melihat data yang didapat pada saat katup dibuka $100 \%$ PLTMH hanya dapat menghasilkan daya sebesar $1056 \mathrm{kVA}$ dilalikan cos phi 0,9 menjadi 950,4 watt, jika berdasarkan perhitungan teoritis didapatkan daya sebesar 1142,82 watt sehingga dapat dihitung persentase daya sebagai berikut.

$$
\begin{aligned}
\mathrm{Pp} & =\frac{\mathrm{P} \text { real }}{\mathrm{P} \text { teori }} \times 100 \% \\
\mathrm{Pp} & =\frac{950,4}{1142,82} \times 100 \% \\
\mathrm{Pp} & =83,16 \%
\end{aligned}
$$

\section{KESIMPULAN}


RESISTOR (Elektronika Kendali Telekomunikasi Tenaga Listrik Komputer) Vol. 3 No. 1 e-ISSN : 2621-9700, p-ISSN : 2654-2684

Berdasarkan hasil pengukuran dan pengujian sistem diperoleh beberapa kesimpulan sebagai berikut :

1. Berdasarkan percobaan dan perhitungan generator PLTMH hanya menghasilkan daya $83,16 \%$ dari data name plate nya.

2. Berdasarkan percobaan didapat semakin besar beban yang di supply PLTMH maka tegangan dan frekuensinya akan menurun.

3. Berdasarkan percobaan juga didapat semakin tinggi kecepatan putar generator maka frekuensi juga semakin bertambah.

4. Berdasarkan percobaan juga didapat bahwa pembebanan mempengaruhi frekuensi dan tegangan yang dihasilkan oleh generator walaupun tidak signifikan.

\section{DAFTAR PUSTAKA}

[1] M. Mahalla, S. Suharyanto, and M. Isnaeni, "Evaluasi Kinerja IMAG pada Pembangkit Listrik Tenaga Mikrohidro Cokro Tulung Kabupaten Klaten," Jurnal Nasional Teknik Elektro dan Teknologi Informasi (JNTETI), vol. 2, no. 1, pp. 72-77, 2013.

[2] S. Nababan, E. Muljadi, and F. Blaabjerg, “An overview of power topologies for micro-hydro turbines," in 2012 3rd IEEE International Symposium on Power Electronics for Distributed Generation Systems (PEDG), 2012, pp. 737-744.

[3] P. T. Rompas, "Analisis pembangkit listrik tenaga mikrohidro (pltmh) pada daerah aliran sungai ongkak mongondow di desa muntoi kabupaten bolaang mongondow," Jurnal Penelitian Saintek, vol. 16, no. 2, pp. 160-171, 2011.

[4] A. S. D. Ramdhani, Studi Perencanaan PLTMH $1 \times 12 \mathrm{~kW}$ sebagai Desa Mandiri Energi di Desa Karangsewu, Cisewu, Garut, Jawa Barat. Surabaya, 2008.

[5] A. Supardi and J. Susilo, "Pengaruh Pembebanan terhadap Karakteristik Keluaran Generator Induksi 1 Fase,” 2014.

[6] A. A. Larasakti, S. Himran, and A. S. Arifin, "Pembuatan dan Pengujian Pembangkit Listrik Tenaga Mikrohidro Turbin Banki Daya 200 Watt," Jurnal Mekanikal, vol. 3, no. 1, 2012.

[7] H. Muchtar and F. Said, "Sistem Identifikasi Plat Nomor Kendaraan Menggunakan Metode Robert Filter dan Framing Image Berbasis Pengolahan Citra Digital," RESISTOR (elektRonika kEndali telekomunikaSI tenaga
liSTrik kOmputeR), vol. 2, no. 2, pp. 105-112, 2019.

[8] B. Budiyanto and F. Fadliondi, "The Improvement of Solar Cell Output Power Using Cooling and Reflection from Mirror," International Journal of Power Electronics and Drive Systems, vol. 8, no. 3, p. 1320, 2017.

[9] E. Dermawan, P. G. Chamdareno, and A. R. Priyono, "Studi Analisa Start-Up Gas Turbin Memanfaatkan Generator Utama sebagai Motor Penggerak Mula dengan Menggunakan Static Frequency Converter (Sfc) pada Unit Blok 1-2 PT. PJB Unit Pembangkitan Muara Tawar," RESISTOR (elektRonika kEndali telekomunikaSI tenaga liSTrik kOmputeR), vol. 2, no. 2, pp. 83-88, 2019.

[10] F. Fadliondi, H. Isyanto, and B. Budiyanto, "Bypass Diodes for Improving Solar Panel Performance," International Journal of Electrical and Computer Engineering, vol. 8, no. 5 , p. 2703, 2018.

[11] F. Fadliondi, M. Kunta Biddinika, and S. I. Omi, "The Humidity Dependence of Pentacene Organic Metal-OxideSemiconductor Field-Effect Transistor.," Telkomnika, vol. 15, no. 2, 2017.

[12] P. G. Chamdareno, E. Dermawan, and H. Octafriandi, "Desain dan Analisa Permanen Magnet Motor Sinkron untuk Aplikasi pada Lift," RESISTOR (elektRonika kEndali telekomunikaSI tenaga liSTrik kOmputeR), vol. 2, no. 2, pp. 113-120, 2019.

[13] F. Fadliondi, H. Isyanto, and P. G. Chamdareno, "The comparison of organic field effect transistor (OFET) structures," in 2017 2nd International Conference on Frontiers of Sensors Technologies (ICFST), 2017, pp. 6-9.

[14] H. Isyanto and A. Nandiwardhana, "Perancangan DC Cooler Berbasis Internet of Things," RESISTOR (elektRonika kEndali telekomunikaSI tenaga liSTrik kOmputeR), vol. 2, no. 2, pp. 95-104, 2019.

[15] R. Samsinar, D. Almanda, and E. Priatna, "Sistem Pengingat Ganti Oli Berdasarkan Running Hours Mesin, Lama Waktu Pemakaian dan Kekentalan Oli pada Mesin Wire Drawing Berbasis Raspberry Pi 1," RESISTOR (elektRonika kEndali telekomunikaSI tenaga liSTrik kOmputeR), vol. 2, no. 2, pp. 121-130, 2019. 
RESISTOR (Elektronika Kendali Telekomunikasi Tenaga Listrik Komputer) Vol. 3 No. 1 e-ISSN : 2621-9700, p-ISSN : 2654-2684

[16] S. Bahri and P. S. Yuza, "Analisa Kerusakan (Deformasi) Engine Mounting Kendaraan Toyota Agya Berdasarkan Tingkat Vibrasi Berbasis Mem Accelerometer," RESISTOR (elektRonika kEndali telekomunikaSI tenaga liSTrik kOmputeR), vol. 2, no. 2, pp. 131-136, 2019. 
RESISTOR (Elektronika Kendali Telekomunikasi Tenaga Listrik Komputer) Vol. 3 No. 1 e-ISSN : 2621-9700, p-ISSN : 2654-2684 